\title{
GMR
}

\section{Comparative analysis of protocols for DNA extraction from soybean caterpillars}

\author{
J. Palma ${ }^{1}$, I. Valmorbida ${ }^{2}$ I.F.D. da Costa $^{3}$ and J.V.C. Guedes ${ }^{4}$ \\ ${ }^{1}$ Setor de Entomologia, Cooperativa Central Gaúcha Ltda, Unidade de Tecnologia, \\ Cruz Alta, RS, Brasil \\ ${ }^{2}$ Centro de Ciências Rurais, Universidade Federal de Santa Maria, Santa Maria, \\ RS, Brasil \\ ${ }^{3}$ Programa de Pós-Graduação em Agronomia, Centro de Ciências Rurais, \\ Clínica Fitossanitária, Departamento de Defesa Fitossanitária, \\ Universidade Federal de Santa Maria, Santa Maria, RS, Brasil \\ 4Programa de Pós-Graduação em Agronomia, Centro de Ciências Rurais, \\ Laboratório de Manejo Integrado de Pragas, Departamento de Defesa Fitossanitária, \\ Universidade Federal de Santa Maria, Santa Maria, RS, Brasil \\ Corresponding author: J. Palma \\ E-mail: janine.palma@gmail.com \\ Genet. Mol. Res. 15 (2): gmr.15027904 \\ Received October 26, 2015 \\ Accepted December 11, 2015 \\ Published April 7, 2016 \\ DOI http://dx.doi.org/10.4238/gmr.15027904
}

ABSTRACT. Genomic DNA extraction is crucial for molecular research, including diagnostic and genome characterization of different organisms. The aim of this study was to comparatively analyze protocols of DNA extraction based on cell lysis by sarcosyl, cetyltrimethylammonium bromide, and sodium dodecyl sulfate, and to determine the most efficient method applicable to soybean caterpillars. DNA was extracted from specimens of Chrysodeixis includens and Spodoptera eridania using the aforementioned three methods. DNA quantification was performed using spectrophotometry and high molecular weight DNA ladders. The purity of the extracted DNA was determined by calculating the A260/A280 ratio. Cost and time for each DNA extraction method were estimated and analyzed statistically. The amount of DNA extracted by these three methods was sufficient for PCR 
amplification. The sarcosyl method yielded DNA of higher purity, because it generated a clearer pellet without viscosity, and yielded high quality amplification products of the COI gene I. The sarcosyl method showed lower cost per extraction and did not differ from the other methods with respect to preparation times. Cell lysis by sarcosyl represents the best method for DNA extraction in terms of yield, quality, and cost effectiveness.

Key words: Chrysodeixis includens; PCR; Spodoptera eridania; Sarcosyl

\section{INTRODUCTION}

Several studies using molecular markers based on polymerase chain reaction (PCR) have been conducted to characterize the molecular variability and genetic structure of members of the family Noctuidae (Luque et al., 2002; Martinelli et al., 2006; Barbosa et al., 2014). The first step is DNA extraction, and there are many studies with different protocols. The major difference between DNA extraction protocols lies in the buffer composition. The buffer typically includes a buffering agent, a salt to dissociate the DNA from proteins, and a detergent, such as sodium dodecyl sulfate (SDS), cetyltrimethylammonium bromide (CTAB) and sarcosyl, to solubilize the membranes and to aid the inactivation of some enzymes (Sambrook et al., 1989; Cheung et al., 1993; Black and Duteau, 1997).

Extraction of pure and high-quality DNA is a prerequisite for any molecular analysis. The problems often associated with DNA extraction is contamination by proteins, polyphenols, polysaccharides, and lipids (Romano and Brasileiro, 1999; Hoy, 2003; Demeke and Jenkins, 2010). Furthermore, contaminants may interfere with molecular processes, inhibiting PCR (Pandey et al., 1996; Demeke and Jenkins, 2010). Numerous DNA extraction techniques used in different organisms have been described in the literature (Luque et al., 2002; Sosa-Gómez, 2004; Schroeder and Degen, 2008). However, few studies are concerned with comparing extraction methods aimed at finding the most appropriate method for use in each species or family (Rampelotti et al., 2008; Chen et al., 2013), or to compare the efficiency of the techniques, especially for soybean caterpillars.

The soybean looper, Chrysodeixis includens (Walker, 1858) (Lepidoptera: Noctuidae, Plusiinae) is a serious pest of soybean, and is widely distributed in Brazil. It feeds primarily on leaves, and was recently found to cause damage to soybean pods (Moscardi et al., 2012; Czepak and Albernaz, 2014). The Southern armyworm, Spodoptera eridania (Stoll, 1782) (Lepidoptera: Noctuidae) is considered a secondary soybean pest in Brazil; however, outbreaks of this pest have been found in several different regions, and in contrast to $C$. includens, this species can feed on both leaves and soybean pods (Papa and Celoto, 2007; Guedes et al., 2010; Marsaro Júnior et al., 2010). In this study, we evaluated three DNA extraction protocols for Lepidoptera using the integuments of $C$. includens and $S$. eridania caterpillars. In addition, we evaluated the factors that affect the purity, quality, and amount of DNA extracted, as well as the cost effectiveness of the extraction methods, to determine the most efficient protocol for DNA extraction from the species in study.

\section{MATERIAL AND METHODS}

\section{Insects}

Specimens of $C$. includens and $S$. eridania were collected in the state of Goiás, in soybean fields during the 2011/2012 growing season. The caterpillars collected were immediately immersed 
in $96 \%$ alcohol contained in $50 \mathrm{~mL}$ falcon tubes, and transported to the Integrated Pest Management Laboratory (LabMIP), at the Federal University of Santa Maria (UFSM). Subsequently, the caterpillars were washed individually in sterile distilled water, dried on paper towels, and stored in $1.5-\mathrm{mL}$ microfuge tubes at $-20^{\circ} \mathrm{C}$. The identification of $C$. includens and $\mathrm{S}$. eridania was performed by morphological analyses confirming previously described morphological (Angulo and Weigert, 1975; Eichlin, 1975; Eichlin and Cunningham, 1978) and color characteristics of each specimen (Passoa, 1991; Heppner, 1998).

\section{DNA extraction}

Teguments from larvae of $C$. includens and S. eridania were dissected and washed with sterile distilled water. For each species, approximately $150 \mathrm{mg}$ of tegument was used for the extraction of genomic DNA. Extractions were performed at the Plant Pathology Laboratory at UFSM. Three protocols employed for DNA extraction of Lepidoptera were used in the experiment, and each extraction, carried out in duplicates, was performed according to the procedures described in the methods below. At the end of each extraction, the pellet was suspended in $50 \mu \mathrm{L}$ sterile ultrapure water. The color of the DNA pellet in each tube was recorded.

Method 1: the cell lysis by sarcosyl method (Cheung et al., 1993; Sosa-Gómez, 2004) was modified. Tissues were homogenized in $600 \mu \mathrm{L}$ extraction buffer $(200 \mathrm{mM}$ Tris- $\mathrm{HCl}, \mathrm{pH}$ 8.0, $70 \mathrm{mM}$ EDTA, $2 \mathrm{M} \mathrm{NaCl}$, and $20 \mathrm{mM}$ sodium metabisulfite) in a microfuge tube. To this, $150 \mu \mathrm{L} 5 \%$ L-sarcosyl loril was added and incubated at $65^{\circ} \mathrm{C}$ for $5 \mathrm{~min}$. Subsequently, $7.5 \mu \mathrm{L}$ of $10 \mathrm{mg} / \mathrm{mL}$ of Proteinase $\mathrm{K}$ was added, incubated at $65^{\circ} \mathrm{C}$ for $60 \mathrm{~min}$, and centrifuged at $13,000 \mathrm{rpm}$ for $15 \mathrm{~min}$. Following centrifugation, the supernatant was transferred to a new microfuge tube, and an equal volume of chloroform:isoamyl alcohol (24:1) was added and then centrifuged at 13,000 rpm for $15 \mathrm{~min}$. The aqueous phase was transferred to a new microfuge tube, and the chloroform:isoamyl alcohol purification step was repeated. After this purification step, $10 \mu \mathrm{g} / \mathrm{mL}$ RNase was added and incubated at $37^{\circ} \mathrm{C}$ for $30 \mathrm{~min}$. The DNA was precipitated with $600 \mu \mathrm{L} 100 \%$ isopropanol and $405 \mu \mathrm{L} 5 \mathrm{M}$ ammonium acetate, kept overnight at $4^{\circ} \mathrm{C}$ and centrifuged at $13,000 \mathrm{rpm}$ for $15 \mathrm{~min}$ in the following day. The resulting DNA pellet was washed with $400 \mu \mathrm{L} 70 \%$ ethanol, centrifuged at $13,000 \mathrm{rpm}$ for $5 \mathrm{~min}$, and air-dried.

Method 2: based on cell lysis by CTAB (Black and Duteau, 1997; Martinelli et al., 2007) was used. Tissues were homogenized in $500 \mu \mathrm{L}$ extraction buffer $(100 \mathrm{mM}$ Tris- $\mathrm{HCl}, \mathrm{pH}$ 8.0, $1.4 \mathrm{M}$ $\mathrm{NaCl}, 0.02 \mathrm{mM}$ EDTA, $2 \% \mathrm{CTAB}$, and $0.2 \% \beta$-mercaptoethanol), and $10 \mu \mathrm{L} 10 \mathrm{mg} / \mathrm{mL}$ proteinase $\mathrm{K}$ was added, and the homogenate was incubated at $65^{\circ} \mathrm{C}$ for $2 \mathrm{~h}$. Then, $10 \mathrm{mg} / \mathrm{mL}$ RNase was added, homogenized at $37^{\circ} \mathrm{C}$ for $3 \mathrm{~h}$ and centrifuged at $13,000 \mathrm{rpm}$ for $5 \mathrm{~min}$. After homogenization, 500 $\mu \mathrm{L}$ chloroform:isoamyl alcohol (24:1) was added and samples were centrifuged at $13,000 \mathrm{rpm}$ for $20 \mathrm{~min}$. The aqueous phase was transferred to a new microfuge tube and the chloroform:isoamyl alcohol step was repeated. The DNA was precipitated with $400 \mu \mathrm{L} 100 \%$ isopropanol and incubated at $4^{\circ} \mathrm{C}$ for $8 \mathrm{~h}$. Afterwards, the precipitate was centrifuged at $13,000 \mathrm{rpm}$ for $30 \mathrm{~min}$. The resulting DNA pellet was washed twice with $500 \mu \mathrm{L} \mathrm{100 \%} \mathrm{ethanol,} \mathrm{and} \mathrm{centrifuged} \mathrm{at} \mathrm{13,000} \mathrm{rpm} \mathrm{for} 5$ min. Finally, the pellet was air-dried.

Method 3: based on cell lysis by SDS (Sambrook et al., 1989; Luque et al., 2002) was used. Tissues were macerated with $700 \mu \mathrm{L}$ extraction buffer $(10 \mathrm{mM}$ Tris- $\mathrm{HCl}, \mathrm{pH} 7.5,75 \mathrm{mM}$ $\mathrm{NaCl}$, and $25 \mathrm{mM}$ EDTA); following which, $10.5 \mu \mathrm{L} 10 \mathrm{mg} / \mathrm{mL}$ proteinase $\mathrm{K}, 35 \mu \mathrm{L} 20 \% \mathrm{SDS}$, and $70 \mu \mathrm{L} 1 \%$ beta-mercaptoethanol was added to the homogenate and incubated at $65^{\circ} \mathrm{C}$ overnight. Subsequently, $500 \mu \mathrm{L}$ chloroform:isoamyl alcohol (24:1) was added and the samples were 
centrifuged at $14,000 \mathrm{rpm}$ for $50 \mathrm{~min}$. The aqueous phase was transferred to a new microfuge tube and the chloroform:isoamyl alcohol step was repeated. The DNA was precipitated with $800 \mu \mathrm{L} 100 \%$ isopropanol, incubated for $5 \mathrm{~min}$ at room temperature, and centrifuged at 14,000 rpm for $15 \mathrm{~min}$. The pellet was washed with $500 \mu \mathrm{L} 70 \%$ ethanol, centrifuged at $1300 \mathrm{rpm}$ for $5 \mathrm{~min}$, and then air dried.

\section{Detection of DNA quality and quantity}

The DNA obtained from each of the protocols $(1 \mu \mathrm{L})$ was stained with Blue Green I Dye Loading (LGC Biotechnology, California, USA), and analyzed on 1\% agarose gels at $90 \mathrm{~V}$ in $1 \mathrm{X}$ TBE running buffer (90 mM Tris base, $90 \mathrm{mM}$ boric acid, and $2 \mathrm{mM}$ EDTA, pH 8.0). DNA bands were observed on a UV-transluminator, and images were scanned with an image capture system. Electrophoresis not only ascertained the quantity and quality of DNA, but also the presence or absence of degraded molecules. The amount of DNA in the samples was compared with the high molecular marker DNA Mass Ladder (Invitrogen Life Technologies, Carlsbad, CA) using the Kodak Digital Science 1D Image Analysis Software (Kodak Eastman) following manufacturer protocol. DNA concentration was measured with a spectrophotometer (FEMTO Cirrus ST 80, São Paulo, Brazil) at a wavelength of $260 \mathrm{~nm}$. The 260/280 ratio was used to characterize the purity of the extracted material. All DNA samples were stored at $-20^{\circ} \mathrm{C}$ for later use in PCRs.

\section{Analyses by PCR}

PCRs were performed with $1 \mu \mathrm{L}$ each, of the DNA extracted by the three protocols from C. includens and S. eridania. The primers LCO1490 (5'-GGTCAACAAATAAAGATATTGG-3') and HCO2198 (5'-TAAACTTCAGGGTGACCAAAAAATCA-3'), were used to amplify a 709 bp sequence of the COI I (mitochondrial Cytochrome c oxidase subunit I) gene (Folmer et al., 1994). The reaction contained $1 \mathrm{X}$ reaction buffer $(500 \mathrm{mM}$ Tris- $\mathrm{HCl}, \mathrm{pH} 8.5,150 \mathrm{mM}$ ammonium sulfate, $\mathrm{pH} 9.3,25$ $\mathrm{mM} \mathrm{MgCl}_{2}$, and $1 \%$ Tween 20), $0.2 \mathrm{mM}$ of each primer, $0.1 \mathrm{mM}$ of each dNTP (Sigma-Aldrich, St. Louis, MO, USA), and $2.5 \mathrm{U}$ of Taq DNA polymerase (Sigma-Aldrich) in a final volume of $25 \mu \mathrm{L}$. The reaction conditions followed an initial denaturation cycle at $94^{\circ} \mathrm{C}$ for $4 \mathrm{~min}$, followed by 25 cycles of $94^{\circ} \mathrm{C}$ for $1 \mathrm{~min}, 50^{\circ} \mathrm{C}$ for $1 \mathrm{~min}, 72^{\circ} \mathrm{C}$ for $1 \mathrm{~min}$ and 30 seconds, with a final extension at $72^{\circ} \mathrm{C}$ for 5 min, in a PTC-100TM thermocycler (MJ Research, Quebec, Canada). The amplified products were stained with Blue Green Loading Dye I (LGC Biotechnology), and analyzed by electrophoresis on $1 \%$ agarose gels at $90 \mathrm{~V}$. The size of the amplified fragment was estimated by comparing with corresponding bands on a $1 \mathrm{~kb}$ molecular marker (Sigma-Aldrich).

\section{Cost and time required by each method}

The cost for each method was estimated based on the price of chemicals, and enzymes consumed for one extraction from a single caterpillar. The cost ranges were generated by prices paid in the year of extraction (2012). The time required to complete one extraction from a single caterpillar using each method was estimated based on the procedures used in this study. Only $C$. includens data was used to calculate time and cost of extractions.

\section{Analysis of results}

Protocols were compared in terms of the quantity and quality of extracted DNA, the cost 
per reaction, time taken in each procedure to extract a sample of DNA, and performance in PCRs. The preparation time data and cost of DNA extraction were statistically analyzed by the $t$-test at the $5 \%$ probability level, using Assistat 7.7 beta software (Silva and Azevedo, 2009).

\section{RESULTS}

\section{Quantity and quality of DNA}

All three methods generated a pellet of DNA at the end of each extraction. However, the color of the precipitated DNA varied across methods (Table 1). The pellet colors ranged from clear, light yellow, and yellow to light brown and dark brown. DNA extraction methods 2 and 3 produced a light yellow and yellow pellet from C. includens samples, and light to dark brown from S. eridania samples, whereas method 1 generated clear pellets for samples from both species (Table 1). DNA suspension in both methods 2 and 3 showed viscosity in C. includens and S. eridania samples.

DNA extracted by the three methods from the two species formed a full band of approximately $13 \mathrm{~Kb}$ when compared to the molecular markers in the High DNA Mass Ladder. Moreover, all the samples were free of RNA, because there were no lower molecular weight bands observed on the gel (Figure 1). The concentrations as determined by spectrophotometry ranged from 1730 to $1830 \mathrm{ng} /$ $\mu \mathrm{L}$ for $\mathrm{C}$. includens, and 1680 to $1800 \mathrm{ng} / \mu \mathrm{L}$ for S. eridania (Table 1 ). The concentration observed by gel electrophoresis was $1096 \mathrm{ng} / \mu \mathrm{L}$ by method 3 , and $849 \mathrm{ng} / \mu \mathrm{L}$ by method 1 for $C$. includens; and $602 \mathrm{ng} / \mu \mathrm{L}$ by method 2 , and $355 \mathrm{ng} / \mu \mathrm{L}$ by method 3 for S. eridania (Table 1). The A260/A280 ratios ranged between 1.125 and 1.094 in method 1 and method 3, respectively, for $C$. includens, and 1.137 and 1.089 in method 1 and 2, respectively, for S. eridania (Table 1).

Table 1. Quantification and purity of DNA, DNA pellet color, estimated cost, and time used, by three DNA extraction methods to extract DNA from one caterpillar of Chrysodeixis includens and Spodoptera eridania.

\begin{tabular}{l|c|c|c|c|c|c}
\hline \multirow{2}{*}{} & \multicolumn{4}{|c}{ Methods } \\
\cline { 2 - 7 } & \multicolumn{3}{|c}{ C. includens } & \multicolumn{3}{c}{ S. eridania } \\
\cline { 2 - 7 } & Sarcosyl & CTAB & SDS & Sarcosyl & CTAB & SDS \\
\hline A260 & 0.354 & 0.366 & 0.347 & 0.336 & 0.341 & 0.361 \\
\hline A260/280 & 1.125 & 1.107 & 1.094 & 1.137 & 1.089 & 1.100 \\
\hline Concentration $^{1}(\mathrm{ng} / \mu \mathrm{L})$ & 1770 & 1830 & 1730 & 1680 & 1700 & 1800 \\
\hline Concentration with marker $^{2}(\mathrm{ng} / \mu \mathrm{L})$ & 849 & 785 & 1096 & 493 & 602 & 355 \\
\hline DNA pellet color $_{\text {Preparation time }^{*}(\mathrm{~h})}$ & Clear & Light yellow & Yellow & Light yellow & Light brown & Dark brown \\
\hline Cost per sample $^{3 *}(\mathrm{BRL} \$)$ & $13 \mathrm{a}^{\mathrm{b}}$ & $17^{\mathrm{a}}$ & $12^{\mathrm{b}}$ & - & - & - \\
\hline
\end{tabular}

${ }^{1}$ Concentration $=\mathrm{A} 260 \times 100 \times 0.05 \mathrm{ng} / \mu \mathrm{L} .{ }^{2}$ Comparison with the molecular marker High DNA Mass Ladder (Invitrogen). ${ }^{3}$ Considering 2012 values. *Averages indicated by the same letter do not differ statistically according to the Tukey's test at the $5 \%$ level.

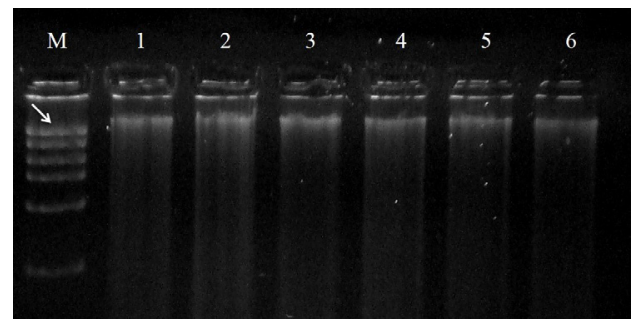

Figure 1. Electrophoresis of the DNA extracted from Chrysodeixis includens (lanes 1-3) and Spodoptera eridania (lanes 4-6). Lane $M=$ high Mass DNA ladder (Invitrogen). Lanes 1 and $4=$ method 1 (sarcosyl). Lanes 2 and $5=$ method 2 (CTAB). Lanes 3 and $6=$ method 3 (SDS). Arrow indicates 10-kb band. 


\section{Cost and time consumed}

In relation to the cost per extraction, method 1 had the lowest cost $(R \$ 4.30)$, which is statistically different from that of the other methods. The preparation time for each method showed no statistical difference, considering that method 2 was the slowest, taking 17 hours to complete the DNA extraction (Table 1).

\section{PCR analysis}

Comparison of PCR amplifications among the tested methods is shown in Figure 2. The DNA extracted from $C$. includens by the three methods was amplified with the primers for the COI I gene, resulting in a clear band of approximately $709 \mathrm{bp}$. Amplification products from DNA samples of $S$. eridania obtained by methods 1 and 2 also generated fragments of similar size. The DNA sample of $S$. eridania obtained by method 3 failed to amplify.

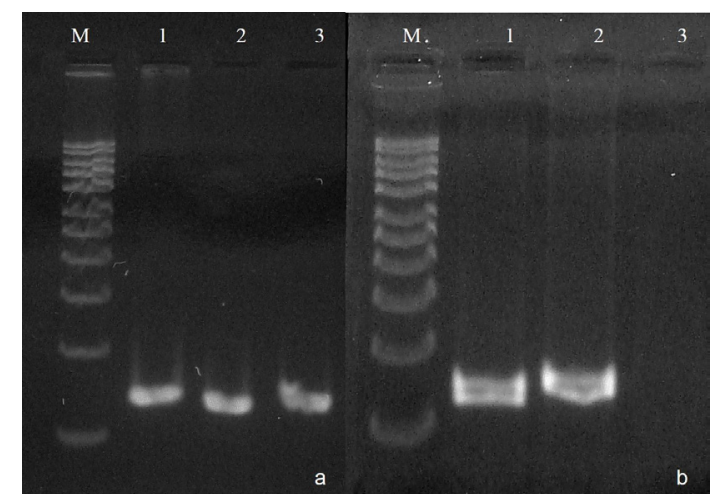

Figure 2. PCR amplification products of the COI gene from Chrysodeixis includens (a) and Spodoptera eridania (b). Lane $M=1-\mathrm{kb}$ molecular weight marker. Lane $1=$ method 1 (sarcosyl). Lane $2=\operatorname{method} 2$ (CTAB). Lane $3=$ method 3 (SDS).

\section{DISCUSSION}

In this study, we evaluated three DNA extraction methods based on cell lysis by sarcosyl, CTAB, and SDS, in two soybean caterpillar species, $C$. includens and S. eridania. Comparing the methods, the DNA extracted by the sarcosyl method produced better results. Method 1 (sarcosyl) generated, at the end of the extraction, a pellet without viscosity, amplified the fragment of the COI I gene, and also had lower costs and preparation time as compared to the other methods tested. However, the purity was lower than expected in all methods, which might indicate the presence of factors that inhibit PCR.

The darkened pellet generated by methods 2 and 3 for both species may indicate the presence of contaminants such as polyphenols, which have not been eliminated during DNA extraction despite the addition of $\beta$-mercaptoethanol, a reagent that removes polyphenols which have an inhibiting effect on DNA oxidation (Romano and Brasileiro, 1999). Another factor that may indicate the presence of contaminants is the visual analysis of the viscosity of pellets. Pellets from methods 2 and 3 had viscosity in both $C$. includens and S. eridania, indicating the presence of polysaccharides that also can inhibit PCR (Chiari et al., 2009; Demeke and Jenkins, 2010). 
The A260/A280 ratio of less than 1.6-1.8 indicates contamination with protein and/or polysaccharide remnants of the insect tissue (Pandey et al., 1996; Demeke and Jenkins, 2010). On the other hand, contamination with polysaccharides seems more likely, since the protocols contained two purification steps with chloroform and the addition of proteinase $\mathrm{K}$ enzyme, which degrades proteins. Chloroform is responsible for denaturation and removal of proteins and lipids (Hoy, 2003). Furthermore, the viscosity of the suspended DNA may indicate higher contamination by polysaccharides in the DNA extracted using methods 2 and 3 , which corroborates with the lowest A260/A280 ratio observed for these methods. However, the bands did not show a conical shape towards the positive pole nor was DNA retained in the wells after electrophoresis (Figure 1). Conical shape towards the positive pole and excess DNA retained in the wells indicate contamination by polysaccharides (Romano and Brasileiro, 1999). In method 1, DNA is precipitated with ammonium acetate, which helps eliminate polysaccharides (Romano and Brasileiro, 1999), but it also may have been responsible for the minor indications of contamination observed in method 1.

One hypothesis for the observed low A260/A280 ratios is that DNA storage time can influence DNA quantification. The extracted DNA was stored for 6 months before quantification by spectrophotometry. As is known, the shorter the DNA storage time, the better is the purity as observed by spectrophotometry analyses (Caldart et al., 2011). Therefore, the value of the A260/ A280 ratio should not be considered conclusive for the comparison between the methods tested.

All methods tested produced enough DNA to be use in PCRs. The molecular analyses were based on the use of $20 \mathrm{ng}$ DNA as templates for each PCR reaction in others studies (Luque et al., 2002; Martinelli et al., 2006; Barbosa et al., 2014). DNA extracted from C. includens by all three methods was amplified by PCR, indicating a sufficient amount and good condition of DNA with low contamination. However, the DNA obtained from $S$. eridania by method 3 was not amplified, and this might be associated with the presence of contaminants such as polyphenols, polysaccharides, and proteins, after extraction (Pandey et al., 1996; Romano and Brasileiro, 1999; Demeke and Jenkins, 2010).

Even if the three methods have been used previously for DNA extraction in Noctuidae, and utilized in PCR assays (Luque et al., 2002; Sosa-Gómez, 2004; Martinelli et al., 2007), the comparison made in this study was positive in the search for a protocol that best suits the demands of laboratory extraction. Among the tested protocols, the method based on cell lysis by sarcosyl was the best in terms of quantity, quality, and cost effectiveness, generating consistently highquality DNA to be used in molecular studies based on PCR.

\section{Conflicts of interest}

The authors declare no conflicts of interest.

\section{ACKNOWLEDGMENTS}

The authors thank the Universidade Federal de Santa Maria for support in implementing this research. We also thank the Coordenação de Aperfeiçoamento de Pessoal de Nível Superior (CAPES) for providing scholarships.

\section{REFERENCES}

Angulo AO and Weigert TG (1975). Estados inmaduros de lepidópteros nóctuidos de importancia económica en Chile y claves para su determinación (Lepidoptera: Noctuidae). Sociedad de Biologia de Concepción, Concepción. 153p. 
Barbosa NCCP, Freitas S and Morales AC (2014). Distinct genetic structure in populations of Chrysoperla externa (Hagen) (Neuroptera, Chrysopidae) shown by genetic markers ISSR and COI gene. Rev. Bras. Entomol. 58: 203-211. http:// dx.doi.org/10.1590/S0085-56262014000200012

Black WC and Duteau NM (1997). The molecular biology of insect disease vectors: a methods manual. In: RAPD-PCR and SSCP analysis for insect population genetic studies (Crampton, J.M., Beard, C.B. \& Louis, C., eds.). Chapman \& Hall, London, 361-373.

Caldart ET, Chiappetta CM, Lopes EF and Ravazzolo AP (2011). Análise comparativa de métodos de extração de DNA genômico de células do sangue e do leite de pequenos ruminantes. Acta Sci. Vet. 39: 945.

Chen F, Shi J, Luo YQ, Sun SY, et al. (2013). Genetic characterization of the gypsy moth from China (Lepidoptera, Lymantriidae) using inter simple sequence repeats markers. PLoS One 8: e73017. http://dx.doi.org/10.1371/journal.pone.0073017

Cheung WY, Hubert N and Landry BS (1993). A simple and rapid DNA microextraction method for plant, animal, and insect suitable for RAPD and other PCR analyses. PCR Methods Appl. 3: 69-70. http://dx.doi.org/10.1101/gr.3.1.69

Chiari L, Valle JVR and Resende RMS (2009). Comparação de três métodos de extração de DNA genômico para análises moleculares em Stylosanthes guianensis. Available at [http://www.cnpgc.embrapa.br/publicacoes/ct/ct36/CT36.pdf]. Acessed March 31, 2014.

Czepak C and Albernaz KC (2014). Manejo avançado. Cultiv. Gd. Cult. 178: 20-24.

Demeke T and Jenkins GR (2010). Influence of DNA extraction methods, PCR inhibitors and quantification methods on realtime PCR assay of biotechnology-derived traits. Anal. Bioanal. Chem. 396: 1977-1990. http://dx.doi.org/10.1007/s00216$\underline{009-3150-9}$

Eichlin TD (1975). A guide to the adult and larval Plusinae of California (Lepidoptera: Noctuidae). California Department of Food and Agriculture, California.

Eichlin TD and Cunningham HB (1978). The Plusiinae (Lepidoptera: Noctuidae) of America north of Mexico, emphasizing genitalic and larval morphology. No. 1567. United States Department of Agriculture, Washington.</bok>

Folmer O, Black M, Hoeh W, Lutz R, et al. (1994). DNA primers for amplification of mitochondrial cytochrome c oxidase subunit I from diverse metazoan invertebrates. Mol. Mar. Biol. Biotechnol. 3: 294-299.

Guedes JVC, Stecca CS, Rodrigues RB and Bigolin M (2010). Nova dinâmica. Cultiv. Gd. Cult. 139: 24-26.

Heppner JB. (1998). Spodoptera Armyworms in Florida (Lepdoptera: Noctuidae). Available at [http://www.freshfromflorida. com/pi/enpp/ento/entcirc/ent390.pdf]. Acessed April 29, 2015.

Hoy MA (2003). Insect molecular genetics. An introduction to principles and applications. Academic Press/Elsevier, San Diego, $C A$.

Luque C, Legal L, Staudter H, Gers C, et al. (2002). ISSR (inter simple sequence repeats) as genetic markers in noctuids (Lepidoptera). Hereditas 136: 251-253. http://dx.doi.org/10.1034/j.1601-5223.2002.1360312.x

Marsaro Júnior AL, Pereira PRVS, Silva WR, Griffel SCP, et al. (2010). Flutuação populacional de insetos-praga na cultura da soja no Estado de Roraima. Rev. Acad., Ciênc. Agra. Ambient. 8: 71-76.

Martinelli S, Barata RM, Zucchi MI, Silva-Filho MdeC, et al. (2006). Molecular variability of Spodoptera frugiperda (Lepidoptera: Noctuidae) populations associated to maize and cotton crops in Brazil. J. Econ. Entomol. 99: 519-526. http://dx.doi. org/10.1603/0022-0493-99.2.519

Martinelli S, Clark PL, Zucchi MI, Silva-Filho MC, et al. (2007). Genetic structure and molecular variability of Spodoptera frugiperda (Lepidoptera: Noctuidae) collected in maize and cotton fields in Brazil. Bull. Entomol. Res. 97: 225-231. http:// dx.doi.org/10.1017/S0007485307004944

Moscardi F, Bueno AF, Sosa-Gómez DR, Roggia S, et al. (2012). Soja. Manejo integrado de insetos e outros artrópodes-praga. In: Artrópodes que atacam as folhas de soja (Hoffmann-Campo CB, Corrêa-Ferreira BS and Moscardi F, eds.). Embrapa, Brasília, DF, 214-334.

Pandey RN, Adams RP and Flournoy LE (1996). Inhibition of Random Amplified Polymorphic DNAs (RAPDs) by plant polysaccharides. Plant Mol. Biol. Rep. 14: 17-22. http://dx.doi.org/10.1007/BF02671898

Papa G and Celoto F.J. (2007) Lagartas na soja. Available at [http://www.ilhasolteira.com.br/colunas/index.php?acao=verartig o\&idartigo=1189090532]. Acessed May 16, 2011.

Passoa S (1991). Color identification of economically important Spodoptera larvae in Honduras (Lepidoptera: Noctuidae). Insecta Mundi 5: 185-196.

Rampelotti FT, Ferreira A, Tcacenco FA, Martins JFS, et al. (2008). Genetic diversity of Tibraca limbativentris Stål (Hemiptera: Pentatomidae) of Santa Catarina and Rio Grande do Sul, Brazil, using RAPD. Neotrop. Entomol. 37: 20-29. http://dx.doi. org/10.1590/S1519-566X2008000100004

Romano E and Brasileiro ACM (1999). Extração de DNA de plantas. Biotecnolog. Cienc. Desenvolv. 9: 40-43.

Sambrook J, Fritsch EF and Maniatis T (1989). Molecular cloning. A laboratory manual. Cold Spring Harbor Laboratory Press, New York. 
Schroeder H and Degen B (2008). Spatial genetic structure in populations of the green oak leaf roller, Tortrix viridana L. (Lepidoptera, Tortricidae). Eur. J. For. Res. 127: 447-453. http://dx.doi.org/10.1007/s10342-008-0228-4

Silva FAS and Azevedo CAV (2009). Principal components analysis in the software Assistat-Statistical Attendance. American Society of Agricultural and Biological Engineers, Reno-Nv-USA.

Sosa-Gómez DR (2004). Intraspecific variation and population structure of the Velvetbean Caterpillar, Anticarsia gemmatalis Hübner, 1818 (Insecta: Lepidoptera: Noctuidae). Genet. Mol. Biol. 27: 378-384. http://dx.doi.org/10.1590/S1415$\underline{47572004000300012}$ 